\title{
Capital Budgeting Theory and Practice: A Review and Agenda for Future Research
}

\author{
Lingesiya Kengatharan ${ }^{1}$ \\ ${ }^{1}$ Department of Financial Management, University of Jaffna, Sri Lanka. \\ Correspondence: Lingesiya Kengatharan, Department of Financial Management, University of Jaffna, Sri Lanka.
}

Received: December 21, 2015

Accepted: January 14, 2016

Available online: February 4, 2016

doi:10.11114/aef.v3i2.1261

URL: http://dx.doi.org/10.11114/aef.v3i2.1261

\begin{abstract}
The main purpose of this research was to delineate unearth lacunae in the extant capital budgeting theory and practice during the last two decades and ipso facto become springboard for future scholarships. Web of science search and iCat search were used to locate research papers published during the last twenty years. Four criteria have been applied in selection of research papers: be an empirical study, published in English language, appeared in peer reviewed journal and full text research papers. These papers were collected from multiple databases including OneFile (GALE), SciVerse ScienceDirect (Elsevier), Informa - Taylor \& Francis (CrossRef), Wiley (CrossRef), Business (JSTOR), Arts \& Sciences (JSTOR), Proquest ,MEDLINE (NLM), and Wiley Online Library. Search parameters covered capital budgeting, capital budgeting decision, capital budgeting theory, capital budgeting practices, capital budgeting methods, capital budgeting models, capital budgeting tools, capital budgeting techniques, capital budgeting process and investment decision. Thematic text analyses have been explored to analyses them. Recent studies lent credence on the use of more sophisticated capital budgeting techniques along with many capital budgeting tools for incorporating risk. Notwithstanding, it drew a distinction between developed and developing countries. Moreover, factors impinging on choice of capital budgeting practice were identified, and bereft of behavioral finance and event study methodological approach were highlighted. More extensive studies are imperative to build robust knowledge of capital budgeting theory and practice in the chaotic environment. This research was well thought out in its design and contributed by stating the known and unknown arena of capital budgeting during the last two decades. This scholarship facilitates to academics, practitioners, policy makers, and stakeholders of the company.
\end{abstract}

Keywords: Capital budgeting theory and practices, capital budgeting tools for incorporating risk, discount rate

\section{Introduction}

Predominantly, area of capital and capital budgeting of financial management have been attracted many researchers during the last five decades and the seminal studies culminated with presenting many theories (e.g., Markowitz,1952; Modigliani \& Miller,1958; Markowitz,1959; Miller \& Modigliani,1961; Fama,1970; Black \& Scholes,1973; Ross, 1976; Roll,1977; Myers,1977; Myers,1984; Jensen,1986; Ritter,1991;Graham \& Harvey, 2001; Myers,2003; Halov \& Heider,2004; Atkeson \& Cole,2005;) and models (e.g.,Markowitz,1952; Sharpe,1963; Sharpe,1964; Linter,1965; Roll,1977) time to time. Notwithstanding, due to the globalization, environmental changes and cutting edge advanced technological developments, theories and models developed in the past do not applicable today and many of them are criticized and their applicability in practice is intriguing (e.g., Malkiel, 2003; Bornholt, 2013). A curious instance illustrated by Brounen, de Jong and Koedijk (2004) is that 'Nobel Prize winning concepts like the capital asset pricing model and capital structure theorems have been praised and taught in class rooms, but to what the extent to these celebrated notions have also found their way into corporate board rooms remains somewhat opaque' (p.72). 'Traditional capital budgeting methods have been heavily criticized of discouraging the adoption of advanced manufacturing technology and thus undermining the competitiveness of Western firms' (Slagmulder, Bruggeman \& Wassenhove, 1995, p.121). In a similar vein, many research scholars on their seminal scholarships argued that there are gaps in theory of capital budgeting and its applicability (e.g., Mukheijee \& Henderson, 1987; Arnold \& Hatzopoulos, 2000; Graham \& Harvey, 2001; Cooper, Morgan, Redman \& Smith, 2002; Brounen et al., 2004; Kersyte, 2011).

Firms operating in a dynamic environment must respond to changes to beat competitors and to sustain, survive and grow in markets (Ghahremani, Aghaie \& Abedzadeh, 2012). Most changes impinge on capital investment decisions, 
which can invariably involve large sums of money over the long period (e.g.,Peterson \& Fabozzi, 2002, Cooper et al., 2002; Dayananda, Irons, Harrison, Herbohn \& Rowland, 2002) and these decisions are critical in managing strategic change and sustaining long term corporate performance (Emmanuel, Harris \& Komakech, 2010). Capital investment decision can be acquisitions, investing new facilities, new product development, employing new technology and adoption of new business processes or some combination of these (Emmanuel et al., 2010). Capital budgeting investment decisions are critical to survival and long term success for firms due to many factors and those factors are commonly named as uncertainty. The global financial crisis is epitomized this truth. One of the most intractable issues confronted by researchers is how to identify, capture, and evaluate uncertainties associated with long term projects (Haka, 2006). Sources of uncertainty range from the mundane (cash flow estimation, number and sources of estimation error, etc.) to the more esoteric (complementarities among investments, options presented by investment opportunities, opportunity cost of investments, etc.) (Haka, 2006). Since capital investment decision deals with large sum of fund, scrupulous attention has been given in making decision. 'Capital budgeting is as the procedures, routines, methods and techniques used to identify investment opportunities, to develop initial ideas into specific investment proposals, to evaluate and select a project and to control the investment project to assess forecast accuracy'(Segelod,1997). Albeit there are number of capital budgeting methods assist in making decision, number of other uncertainty factors have deleterious penetration into making capital budgeting decision.

Nowadays, complex methods are used for making capital budgeting decision rather purely depends on theories of capital budgeting because of uncertainty and other contingency factors (Singh, Jain \& Yadav, 2012; Zhang, Huang \&Tang, 2011; Kersyte, 2011; Bock \& Truck, 2011; Byrne \& Davis, 2005;Cooper et al, 2002; Arnold \& Hatzopoulos, 2000; Mao, 1970; and Dickerson, 1963). After the advent of full-fledged globalization and in the era of cutthroat competition (Verma, Gupta \& Batra, 2009), advanced developments in technologies, other macro environmental factors and demographic factors are intruding into capital budgeting practices (Verbeeten, 2006). In a world of geo-political, social as well as economic uncertainty, strategic financial management is of process of change, in turn requiring a reexamination of the fundamental assumption (e.g, efficient market hypothesis, Fama,1970) that cut across traditional boundaries of the financial management (Hill, 2008). With limited credit and other sources of financing in today's uncertain and challenging economic environment, also required to be scrupulously evaluated the profitability and successfulness of proposed capital investments and allocate limited capital is more vital than ever (Kester \& Robbins, 2011).

Over the last 20 years, there have been many changes and challenges in making financial decision due to the global financial crisis, fluctuations in value of money, advanced technology, interest rate, exchange rate and inflation rates' risks and dramatic changes in economic and business environment both in national as well as in global markets. Thus, there is need to re- examine and re- study for re-building capital budgeting practices since it has considerable impact on investment decision making. The investment decision making is not a simple or straightforward approach, the risk is an important element in making investment decision. There are number of risk techniques employed by companies for evaluating investment projects. However, there is problem in setting up theoretical model and applying that model into practice (e.g: Arnold \& Hatzopoulos, 2000; Digkerson, 1963). Thus, the theory is not purely able to apply at all times. Sometimes theories developed in the past do not applicable today. There is no doubt, over the last two decades corporate practices regarding capital budgeting practices have not been static, diverged from the theories.

This study presents systematic review on capital budgeting practices literature published in the last two decades. The systematic review of literature is referred to as 'principally justified by the manner in which the reviewer proceeds, stage by stage, with full transparency and explicitness about what is (and what is not) done, typically using a protocol to guide the process' (Young, Ashby, Boaz \& Grayson, 2002, p.220). Through this review, updating information about the capital budgeting techniques which being used by firms and to compare the current usage of various techniques, methods with those found in previous studies. This study is thus accumulatively builds a robust knowledge in the area of capital budgeting practices and identifying unearth gaps will become springboard for future research. Therefore, this research guides the researchers to reflect on and assess where they are in an area of capital budgeting practices and guide future research directions.

\subsection{Objective of the study}

Examining empirical research on capital budgeting practices to date has been very useful in explaining importance of capital budgeting practices for the long time success of the business organization. Nowadays, complex methods are used for making capital budgeting decision rather purely depends on theories of capital budgeting. Advanced developments in technologies, other macro environmental factors and demographic factors are intruding into capital budgeting practices and thus some of the theories become out of use in well developed countries (e.g: payback period). Thus, the main aim of this research is to demonstrate unearth gaps in the existing capital budgeting practices literature and to suggest the directions for the future research. It will further attempt to 
- Explain the capital budgeting theories and practices in different countries and demonstrate the disparities between theories and practices of capital budgeting

- Identify the factors that determine use of capital budgeting practices of a country or firm

\subsection{Problem Statement}

During the past twenty years (1993-2013), the theory of capital budgeting has been characterized by the many increased applications on the basis of risk and uncertainty resulting from global economic, technological and advanced educational changes e.g: inflation risk, interest rate and exchange rate risk. Capital budgeting is the backbone of the financial management. Modern financial management theory generally assumes that the primary objective of a firm is to maximize the wealth of its owners (Atrill, 2009). Uncertainty and risk are the major influence in making investment decision and thus Mao (1970) says 'a central aspect of any theory of capital budgeting is the concept of risk' (p.352). In order to implement the objective of modern financial management theory, 'financial executives need criteria for choosing between alternative time patterns of project evaluations within his planning horizon' (Mao, 1970). There are complexities in making investment decision and the theory could not always applicable in all situations. Problem statement of this study is how far capital budgeting theory differentiates with practice and to demonstrate the nature of the gaps in existing capital budgeting literature.

\subsection{Research Questions}

On the basis of background of research, the following research questions have been developed as the way to attain research objectives.

- What are the capital budgeting theories and practices used by firms? Are there any disparities between the capital budgeting theories and practices? If so how?

- What are the factors determines the use of capital budgeting practices? Are there different across countries? If so how?

- What are the gaps in the existing capital budgeting literature?

\section{Methodology}

The main objective of this study is to find out gaps in extant capital budgeting literature during the past 20 years of study. The methodology covers research philosophy, research approach, research strategy, methods of data collection and data analysis. These entire methodological spheres used throughout the research have been below discussed in details.

\subsection{Research Philosophy}

One of the dominant philosophical concepts is the 'ontological assumption' that enquires about nature of reality, and any study absence of this assumption would be treated as 'blinded' (Easterby-Smith, Thorpe \& Lowe, 2002, p. 27). This research assumes that capital budgeting practices are different across firms/ nations and the ways of looking at capital budgeting practices are not same at all the time. It can be further articulated that even when there are number of capital budgeting theories, we cannot expect similar application at all situations and thus it is subject to changes. Thus, the ontological assumption is of constructionism. Constructionist ontology's view that world is being internally constructed and both individually and collectively generate meaning where we are not sure about what is real! Consequently, people guess reality of the world with the experience of external indicators.

Another important philosophical assumption is the epistemological assumption. It enquires about what should be taken as acceptable knowledge in a particular field (Easterby-Smith et al., 2002). The traditional practices do not applicable in the contemporary borderless global businesses and thus try to understand the factors determine the use of capital budgeting practices. It guides how can we understand and determine capital budgeting practices in different context and in different geographical location. The knowledge can be attainable by text analysis with subject methods. Thus, it offers what is already known about capital budgeting practices and captures the gaps in extant literature by systematically reviewing literature.

This research takes interpretive approach on epistemology for answering research questions. The reality is not independent of individual thought and thus all the research findings are not similar with one another (Blaikie, 2007). Thus, this multiple reality is called 'subjectivism'. Findings could vary in different context such as nature of measurement tools, geographical location, company's size, organizational practices, types of sectors and form of methodology used. Thus, this research is organized by collecting relevant literature review and interpreting concepts of relationship between researchers and research. Inductive approach is thus suited by exploring thematic text analysis.

\subsection{Research approach}

The research strategy leads to design qualitative research approach. This research covered sufficient researches carried 
out during the past two decades in the area of capital budgeting. This research analyzed past literature by identifying relevant themes and then thematic text analysis was employed. Thus, this research is 'subjective' and adopts inductive approach in order to answering research questions.

\subsection{Research strategy}

Research strategy tells about how research should be designed for answering a set of developed research questions and consequently research aims are attained. As this research covers last twenty years of research papers carried out in the area of capital budgeting from 1993 to 2013, this study adapts research strategy of longitudinal research design. However, the collection of literature covers broad areas including different sectors, different locations/countries and different size of firms. Thus, the systematic literature review sometimes takes comparative research design as well.

\subsection{Data collection methods}

Web of science search and iCat search were used to locate research papers published during the last twenty years. Web of science is a mass search engine linking with mass database covering more than 10000 journals and 110000 conference proceedings. However, all most all the databases (online the full text of electronic resources) have been covered by iCat search which is subscribed and launched by Kingston University, London. Kingston University library's access service was exploited for collecting all the research papers. Search parameters includes capital budgeting, capital budgeting decision, capital budgeting theory, capital budgeting practices, capital budgeting methods, capital budgeting models, capital budgeting tools, capital budgeting techniques, capital budgeting process and investment decision.

Initially, there are 363 research papers identified during the last 20 years. Of them, 201 research papers were screened and considered for this research to be reviewed based on the following criteria.

- An empirical study (i.e., sampling process, measurement, analysis): 363 papers were identified

- Published in English language: Of 363, 264 were published in English.

- Should be published in peer reviewed journal : Of 264, 239 were published in a peer reviewed journals

- Full text research papers: Of 239, 201 papers were full text journal

These papers were collected from following databases: OneFile (GALE), SciVerse ScienceDirect (Elsevier), Informa Taylor \& Francis (CrossRef), Wiley (CrossRef), Business (JSTOR), Arts \& Sciences (JSTOR), MEDLINE (NLM), SpringerLink, Wiley Online Library, Inderscience Journals, ERIC (U.S. Dept. of Education), Sage Publications (CrossRef), INFORMS Journals, Health Reference Center Academic (Gale), University of Chicago Press Journals, Emerald Management eJournals, Directory of Open Access Journals (DOAJ),IngentaConnect, IEEE (CrossRef). All these papers were spread over across many journals including Journal of Banking and Finance, The Journal of Finance, Journal of Accounting and Economics, Management Decision, Journal of Cleaner Production, Journal of Financial Economics, Management Science, European Journal of Operational Research, Accounting Review, Journal of Economic Behavior and Organization, Long Range Planning, Energy Policy, Accounting, Organizations and Society, Computers and Mathematics with Applications.

\subsection{Data analysis}

As discussed, at the outset, Miles and Huberman's (1984) proposed strategy was carried out that involves collection, reduction, displays and conclusions. Based on the set criteria, 363 research papers were reduced to 201 and they analyzed using a coding procedure. Initially, collected research papers were grouped into themes or topics. Theme represents the focused area of research and it is selective coding on grounded theory (Corbin \& Strauss, 1990). Themes were in terms of current theory and practices of capital budgeting, factors influencing on capital budgeting practices/ determinants of capital budgeting practices, capital budgeting methods/ models, supplementary tools for the capital budgeting methods, influences of capital budgeting practices on investment decisions, component of capital budgeting process, capital budgeting stages, and global capital budgeting practices.

A thematic analysis was employed to capture key themes and concepts in chosen research papers. In doing so, open coding, as suggested by Strauss and Corbin (1998), was adopted. The analysis was focused on the concepts related to capital budgeting practices and theories, research design, research sampling techniques, research approach, year of publication, nature of industry and so on. The results of this analysis were presented below.

\section{Results}

\subsection{Multi-disciplinary concepts of capital budgeting}

During the past twenty years, a total of 202 research papers appeared in peer reviewed indexed journals were identified across many academic journals. Majority of the papers appeared in Engineering Economist $(\mathrm{N}=32)$ yielding $15.92 \%$ followed by Managerial Finance (27), Public Budgeting \& Finance (16), Financial Management(9), Journal of Banking and Finance (8), Journal of Business Finance \& Accounting (6), Accounting Education(5), Management Accounting 
Research(5), The Journal of Finance(5), Journal of Corporate Accounting \& Finance (4), Management Decision (4) and The Review of Financial Studies. All of these journals represented $62.20 \%$ of research papers in capital budgeting in the last two decades. The reminder of the research papers appeared in many journals. Capital budgeting is thus multi-disciplinary aspects and applied across many discipline. The table 1 below summarizes entire list of journals contained capital budgeting research papers.

Table 1. Name of the journals: Capital budgeting research papers appeared during the past twenty years

\begin{tabular}{|c|c|c|c|}
\hline Name of the Journal & & $\begin{array}{l}\text { ber of } \\
\text { r shed } \\
\text { ished }\end{array}$ & Percentage \\
\hline Engineering Economist & 32 & $15.92 \%$ & \\
\hline Managerial Finance & 27 & $13.43 \%$ & \\
\hline Public Budgeting \& Finance & 16 & $7.96 \%$ & \\
\hline Financial Management & 9 & $4.48 \%$ & \\
\hline Journal of Banking and Finance & 8 & $3.98 \%$ & \\
\hline Journal of Business Finance \& Accounting & 6 & $2.99 \%$ & \\
\hline Accounting Education & 5 & $2.49 \%$ & \\
\hline Management Accounting Research & 5 & $2.49 \%$ & \\
\hline The Journal of Finance & 5 & $2.49 \%$ & \\
\hline Journal of Corporate Accounting \& Finance & 4 & $1.99 \%$ & \\
\hline Management Decision & 4 & $1.99 \%$ & \\
\hline The Review of Financial Studies & 4 & $1.99 \%$ & \\
\hline $\begin{array}{l}\text { Three papers in each journal: Healthcare Financial } \\
\text { Management, Information Sciences, International Journal of } \\
\text { Energy Research, International Journal of Production Economics, } \\
\text { Journal of Financial Economics, Management Science, } \\
\text { Operations Research, The Journal of Business, Theoretical and } \\
\text { Applied Economics. }\end{array}$ & 3 & $1.49 \%$ & \\
\hline $\begin{array}{l}\text { Two papers in each journal: Accounting \& Finance, Accounting } \\
\text { and Business Research, Accounting, Organizations and Society, } \\
\text { Computers \& Industrial Engineering, Computers and } \\
\text { Mathematics with Applications, Contemporary Accounting } \\
\text { Research, European Financial Management, European Journal of } \\
\text { Operational Research, Health care strategic management, } \\
\text { Industrial Management \& Data Systems, International Journal of } \\
\text { Business and Management, Journal of Accounting and } \\
\text { Economics, Journal of Computational and Applied Mathematics, } \\
\text { Journal of Information Technology, Journal of Marketing } \\
\text { Management, Journal of Small Business Management, Journal of } \\
\text { the International Academy for Case Studies, Journal of the } \\
\text { Operational Research Society, Long Range Planning, Managerial } \\
\text { and Decision Economics, The Bond Buyer, The Financial } \\
\text { Review. }\end{array}$ & 2 & $1.00 \%$ & \\
\hline $\begin{array}{l}\text { One paper in each journal: Academy of Marketing Studies } \\
\text { Journal, Accounting Review, Agricultural Finance Review. }\end{array}$ & 1 & $0.50 \%$ & \\
\hline
\end{tabular}


Applied Financial Economics, Australasian Radiology, Australian Journal of Management, BuR : Business Research, Business Forum, Wntr-Spring, Business Process Management Journal, Canadian Journal of Anesthesia/Journal canadien d'anesthésie, Computational Management Science, Computers and Chemical Engineering, Cornell Hotel and Restaurant Administration Quarterly, Energy Policy, European Management Journal, Expert Systems With Applications, Forest Products Journal, Fuzzy Sets and Systems, Healthcare financial management. IEEE Transactions on Engineering Management, Industrial Management, International Journal of Commerce and Management, International Journal of Information Technology \& Decision Making, International Journal of Project Management, International Journal of Quality \& Reliability Management, International Transactions in Operational Research, Journal of Accounting Research, Journal of Cleaner Production, Journal of Economic Behavior and Organization, Journal of Empirical Finance, Journal of Hospitality \& Tourism Research, Journal of International Financial Management \& Accounting, Journal of International Money and Finance, Journal of Management Accounting Research, Journal of Managerial Issues, Journal of Property Investment \& Finance, Journal of Public Health Dentistry, Journal of Retail Banking, Journal of Risk and Insurance, Journal of Teaching in International Business, journal of the Healthcare Financial Management, Knowledge-Based Systems, Management Accounting Quarterly, Mid-Atlantic Journal of Business, Naval Research Logistics (NRL), New Directions for Higher Education, Operations-Research-Spektrum, Quarterly Review of Economics and Finance, Real Estate Economics, Review of Agricultural Economics, Review of Business, Review of Finance and Banking, Review of Quantitative Finance and Accounting, Scandinavian Journal of Management, South East European Journal of Economics and Business, Strategic Finance, The Accounting Review, The European Journal of Finance, The Financier, Spring-Winter, The McKinsey Quarterly, Tsinghua Science \& Technology, UTMS Journal of Economics, Vision: The Journal of Business Perspective, Journal of advances in management research.

Percentages calculated in terms of number of papers appeared in each journal $(N=202)$.

\subsection{Major themes identified in Capital budgeting research}

A total of 201 research papers in capital budgeting have been meticulously reviewed and consequently following major themes have been identified: capital budgeting theory and practices, capital budgeting theory and practices in developed countries, capital budgeting theory and practices in developing countries and factor affecting capital budgeting decision. Findings discusses under identified themes.

\subsection{Capital budgeting theory and practices}

Capital budgeting decisions are crucial and complex and have attracted many research scholars in this field. According to Dayananda et al. (2002), capital budgeting is the process of deciding investment projects which create in maximization of shareholder value. Capital budgeting is mostly dealt with sizable investments in long term assets. Assets can be either tangible such as building, plant, or equipment or intangible assets such as patents, new technology or trade mark (Brealey \& Myers, 2003). Capital budgeting is not a short term aspects, generally prepared a year in advance and extendable to five, ten or even fifteen years in future (Brickley, 2006). And thus, Peterson and Fabozzi (2002) define capital budgeting is the process of analyzing and selecting investment opportunities in long term assets where its benefits last for more than one year.

Capital budgeting is a fundamental and used everywhere as a tool for planning, control, and allocation of scare resources among competing demands. Capital budgeting is a vital part in financial planning and decision making since 
capital budgeting tools leads better decision making and be able to justify selection of specific capital investments among competing alternatives (Sekwat,1999).Decision to choose the best investment project among competing projects is of critical and being taken by top management (Bowman \& Hurry, 1993; McGrath, Ferrier \& Mendelow, 2004) and considerable attention is thus to be given to investigating the methods used in evaluating and selecting investment projects (Sangster, 1993; Segelod, 1998).

The most prevalent capital budgeting techniques in the public finance literature include payback period (PB), accounting rate of return (ARR), net present value (NPV), internal rate of return (IRR), benefit-cost ratio (BCR), and profitability index (PI) (e.g., Sekwat,1999;Cooper et al.,2002). Among these methods, four methods .viz., NPV, IRR, PB and ARR, have been identified as a predominant method and used in many studies (e.g., Pike,1996; Kester, Chang, Echanis, Haikal, Isa, Skully,Tsui \& Wang, 1999; Hermes, Smid, \& Yao, 2007).

The PB model determines the length of time required to recover exactly the invested cash outlay. On the other hand, the ARR is calculated as the ratio of the investment's average after tax income to its average book value (Cooper et al., 2002). The PB period has been criticized for failing to make accurate assessments of project value as it does not consider use of cash flows, time value of money, risk in a systematic manner and further it does not identify investment projects that will maximize profits, therefore PB does not have theoretical justification (Pike, 1988; Lefley,1996). Research scholars and practitioners criticized the ARR due to the ignorance of the time value of money (e.g., Cooper et al., 2002; Ross, Waterfield, Jordan \& Roberts, 2005). And PB methods failed to consider return from the capital investment after the initial outlay recovered, yet it is also oft- used methods (e.g., Graham \& Harvey, 2001; Brounen et al., 2004; Bennouna, Meredith and Marchant, 2010). Researchers argued that the reasons behind widespread use of PB method are of its easiness and of providing information about recovery of initial investment.

Thus, in the next generation, the NPV model came into practice where it measures the difference between present value of the money in and present value of the money out (Cooper et al., 2002). If the NPV is positive, the capital investment is accepted and vice versa. Alternatively, the IRR determines the rate at which capital investment can be acceptable and thus equates the cost of the capital investment to the present value of that project (Cooper et al., 2002). In finance, the methods of assessing capital budgeting using the concepts of the time value of money is called discounted cash flow (DCF) analysis. The NPV and IRR methods are called discounted cash flow (DCF) methods. The PB and ARR methods are considered to be non-DCF methods. 'Capital budgeting theory assumes that projects are evaluated based on economic merit. Building upon certain economic assumptions, including the time value of money, risk aversion, and an assumed goal of value maximization, sophisticated investment appraisal techniques such as NPV and IRR, have been advocated in the literature' (Slagmulder et al., 1995,p.123).Notwithstanding, several researchers criticized that requisite necessary information for NPV and IRR is commonly not known with certainty owing to longer periods, uncertainty in future, higher degree of risk, ignore the size of the investment and absence of logical comparison on time value of money (e.g., Sekwat,1999; Cooper et al.,2002; Hermes et al., 2007).Thus, in order to overcome both the time value of money and the size of the investment, the PI model has been emerged. It is the ratio of the capital investment to its outlay and the decision being made in terms of the highest PI (Cooper et al., 2002). If this method used carelessly with constrained investment resources, it generates bad results (Brealey \& Myers, 2003).

However, Graham and Harvey (2001) reported that twelve capital budgeting methods were in practice: NPV, IRR, Annuity, Earning multiple (P/E), Adjusted present value (APV), PB, Discounted Payback, PI, ARR, Sensitivity analysis, Value at risk and real options. However, all of them are not in usable at all situations in capital budgeting practices. For example, IRR should not be the best method if investments are mutually exclusive or have multiple rates of return, however, IRR is oft-exploited methods in practice (Graham \& Harvey, 2001; Brounen et al., 2004; Bennouna et al., 2010).

Of these methods, discounted payback considers time value of money but it still ignores cash flows after initial outlay recovered. Value-at-risk (VAR) is to measure 'the worst expected loss over a given horizon under normal market conditions at a given confidence level' (Jorion, 2006; p.12), is a relatively new method. The APV additionally covers the value of financial side-effects of an investment to NPV, and treated as having no drawbacks principally (Ross et al., 2005).

The greatest problems of the traditional present value models are that its complete reliance on quantifiable cash flows. However, in a contemporary high tech world, many new projects entail complete redesign of the manufacturing environment and computerized design is of paramount important to be innovative, higher qualities and speedier response (Cooper et al., 2002). And thus, the theory of capital budgeting is diverged from its practices.

The complex nature of the capital investment in today's world incubates many new models into practices including multi-attribute decision model, and analytical hierarchy process that are more subjective (Cooper et al., 2002). Modern theoretical developments in finance views that DCF methods are not the best methods to select capital investment projects: they have severe drawbacks in the analysis of investment projects if the information about future investment 
decision is not available (Brennan \& Schwartz, 1992; Trigeorgis, 1993; Dixit \& Pindyck, 1994). In such a situation, Real Options Reasoning (ROR) and Game Theory (GT) serves as better analytical tools to evaluate such investment projects (Smit \& Ankum, 1993). GT stresses that firm is having an incentive to invest early in the case of fear of pre-emption (Smit, 2003)

Real option theory: Real option is closely related to corporate capital investment decision-making and has been introduced as an alternative approach for investment appraisal under uncertainty. The starting point for real options research was the criticism of traditional strategic investment decision-making and capital budgeting methods. In general, a real option represents or reflects the option or options that a company has when it comes to deciding whether to invest in a project, delay, put it on hold, expand or reduce an investment, or any other flexibility that it may have (Rigopoulos, 2014). ROT involves the use of investment evaluation tools and processes that properly account for both uncertainty and the company's ability to react to new information (Verbeeten, 2006). ROT has operating flexibility (which enables the management to make or revise decisions at a future time, such as expansion or abandonment of the project) and the strategic option value (resulting from interdependence with future and follow-up investments, such as implementation in phases and the postponement of investments) (Verbeeten, 2006). Many researchers have argued that the use of real options analysis has an advantage over NPV, since NPV is not able to capture the value of managerial flexibility (e.g., Ingersoll \& Ross, 1992; Trigeorgis, 1993; Dixit \& Pindyck, 1994). For example, the management could delay, expand, abandon, temporarily close or alter the operation during the project' life. Ross et al. (2005) argued that most capital investment projects have options (i.e., the option to expand, the option to modify, the option to abandon), which have value per se. Although this method has not been applied on a large scale in practice (Hermes et al., 2007), it is mostly applicable in specific industries or situations. DCF techniques are used concurrently with real options in order to determine the true NPV (Amram \& Howe, 2002). Many research scholars have found that only a few firms have employed real options (Graham \& Harvey, 2001; Ryan \& Ryan, 2002; Brounen et al., 2004; Block, 2007; Truong, Partington \& Peat,2008; Verma et al., 2009; Bennouna et al., 2010; Shinoda,2010, Singh et al.,2012; Andres, Fuente \& Martin,2015).

It is obvious that widespread use of sophisticated capital budgeting during the last two decades. Many earliest studies investigated about capital budgeting decision rule, in contrast, recent researches attempted to focus on the use of sophisticated capital budgeting practices (e.g., Miller \& Waller, 2003). Application of sophisticated capital budgeting is more complex, and required the firms to be able to expend cost, time and effort (Busby \& Pitts, 1997; Miller \& Waller, 2003). Thus, it is important to think about the appropriate level use of sophisticated capital budgeting practices to the net benefits against costs. Anyhow, theory, in contrast, suggests that if uncertainty exists, use of sophisticated capital budgeting practices is valuable and the costs would be offset by the gains from successful investments (Verbeeten, 2006). If uncertainty exists, additional information needed to solve the problem of investment dilemma (Miller \& Waller, 2003). It was identified that Canadian firms seem to be increasingly using sophisticated methods when dealing with risk (for example, sensitivity analysis, decision-tree analysis, Monte Carlo simulation, ROR, GT) (Bennouna et al., 2010). Nowadays, there are number of other methods including the project-dependent (risk-adjusted) cost of capital (PDCC), the weighted average cost of capital (WACC), the cost of debt (CD) used in capital budgeting practices. Among them PDCC and WACC are said to be sophisticated method and CD is the least sophisticated method (Hermes et al., 2007).

\subsection{Capital budgeting tools for incorporating risk}

Overall, uncertainty affects future cash flows and causes estimation difficulties. Therefore, various risk analysis and management science techniques have been developed to supplement the traditional present value based decision models. Scholarship on the practice of capital budgeting in many countries has found that firms are increasingly employing more sophisticated capital budgeting techniques in order to make investment decisions over several years (Klammer, 1973; Klammer \& Walker,1984; Pike,1988; Jog \& Srivastava,1995; Gilbert \& Reichart,1995; Farragher, Kleiman \& Sahu,1999; Arnold \& Hatzopoulos, 2000; Brounen et al.,2004; Truong et al., 2008; Baker, Dutta \& Saadi,2011). In the contemporary world, there are a number of sophisticated capital budgeting methods including the oft-cited: Monte Carlo Simulations, Game theory decision rules, Real option pricing, Using certainty equivalents, Decision trees, CAPM analysis / $B$ analysis, Adjusting expected values, Sensitivity analysis/break-even analysis, Scenario analysis, Adaptation of required return/discount rate, IRR, NPV, uncertainty absorption in cash flows, and PB (e.g., Arnold \& Hatzopoulos, 2000; Hall, 2000; Graham \& Harvey, 2001; Ryan \& Ryan, 2002; Murto \& Keppo, 2002; Cooper et al., 2002; Smit, 2003; Sandahl \& Sjogren, 2003; Brounen et al., 2004; Lazaridis, 2004; Lord, Shanahan \& Bogd, 2004; du Toit \& Pienaar, 2005; Verbeeten, 2006; Elumilade, Asaolu \& Ologunde, 2006; Hermes et al., 2007; Leon et al., 2008; Correia \& Cramer, 2008; Verma et al., 2009; Bennouna et al., 2010; Shinoda, 2010; Hall \& Millard, 2010; Dragota et al, 2010; Poudel et al., 2009; Kester \& Robbins, 2011; Maroyi \& Poll, 2012; Singh et al., 2012; Andres et al., 2015). Thus, the complex models of capital budgeting practices are dependent on not only the use of DCF techniques, but also proper cash flows, discount rates and the risk analysis (Brigham \& Ehrhardt, 2002). 


\subsection{Classification of Capital budgeting Practices}

Capital budgeting practices help managers to select $n$ out of $N$ investment projects with the highest profits and an acceptable 'risk of ruin' (Verbeeten, 2006, p.108). By and large, all capital budgeting practices can be subsumed into the categories of sophisticated, advanced and naive (e.g., Haka, 1987; Haka, Gordon \& Pinches, 1985; Verbeeten, 2006; Wolffsen, 2012). Naive practices includes PB, the adaptation of required payback and ARR, and the advanced /NPV based, including Sensitivity analysis/break-even analysis, scenario analysis, the adaptation of required return/discount rate, IRR, NPV, uncertainty absorption in cash flows, MIRR and PI. Farragher et al. (2001) suggested that a degree of sophistication is represented by the use of DCF techniques and incorporating risk into the analysis. Sophisticated capital budgeting methods generally include Monte Carlo simulations, GT, RO, using certainty equivalents, decision trees, CAPM analysis / $B$ analysis, and adjusting expected values (Verbeeten, 2006; Wolffsen, 2012).

\subsection{Capital budgeting theory and practices in developed countries}

This section clearly discusses the capital budgeting theory and practices especially in developed countries. As aforementioned, the capital budgeting practices are the investment decision taken for increasing shareholders value (Dayananda et al., 2002).

Many studies have been conducted about capital budgeting practices in U.S. and Europe (e.g., Pike, 1996; Sangster, 1993; Block, 2007; Herme et al., 2007). Chadwell-Hatfield et al.(1997) conducted a survey among 118 manufacturing firms in the U.S. Results showed that NPV (84\%) and IRR (70\%) were preferred primary methods. However, it was clearly observed that two thirds of firms relied on shorter PB periods rather IRR or NPV. A seminal study carried out by Graham and Harvey (2001) about 'the theory and practice of corporate finance: evidence from the field' and the sample consisted of 392 CFOs in the USA. In larger firms with high debt ratio, CFOs with MBA were more likely to use DCF (75\% NPV and IRR) than their counterparts. Larger firms applied risk-adjusted discount rate whereas small firms opted for Monte Carlo simulation for adjusting risk. In addition, their findings further argued that PB method has not used as a primary tool, however, it kept as a vital secondary tool. Very similar results were reported in Ryan and Ryan's (2002) study where sample consisted of Fortune 1000 companies. Results were found that NPV was most popular technique, followed by IRR. Most of the firms used sensitivity analysis, scenario analysis, inflation adjusted cash flows, economic value added, and incremental IRR along with NPV and IRR. Block (1997) studied about capital budgeting techniques across small business firms operating in the United States. The most popular method was the PB (42.7\%), followed by ARR (22.4\%). Notwithstanding, researchers connotes that small business owners seemed to be increasingly using DCF as the primary method for evaluating.

Cooper et al. (2002) studied capital budgeting practices in fortune 500 companies in America. Sample consisted of 102 chief financial officers reported that commonly used primary capital budgeting model is the IRR and the second is the payback. Ken and Cherukuri (1991) found that IRR was mostly preferred method in larger companies operating in the U.S. NPV was the next preferred method. The widely used discount rate was the WACC (78\%) and the risk was commonly measured by sensitivity analysis $(80 \%)$.Almost similar results were reported in the survey of Fortune 100 firms by Bierman in 1993.

Arnold and Hatzopoulos (2000) conducted a study on "The gap between theory and practice in Capital Budgeting: Evidence from the UK for 300 UK companies (comprising 100 large, 100 medium and small 100). Results of study indicate that UK companies have increasingly adopted the analysis of financial textbooks prescribed. Stage has been reached in which only a small minority do not make use of discounted cash flows, formal risk analysis, adjustment corresponding inflation and post-audit in their study. Study reported however, managers still using simple rules of thumb techniques in UK

Jog and Srivastava (1995) conducted a survey of capital budgeting practices in Corporate Canada and the results showed that the most preferred method was the PB. Similar results were found in the UK in Pike's (1996) study. Further results indicated that decreased use of ARR in Canada and the United Kingdom, respectively. It was identified that Canadian firms seem to be increasingly using sophisticated methods when dealing with risk (for example, sensitivity analysis, decision-tree analysis, Monte Carlo simulation, ROR, GT) (Bennouna et al., 2010).

Drury, Braund and Tayles (1993) surveyed 300 manufacturing companies in the UK about their capital budgeting practices. Results showed that PB (86\%) and IRR (80\%) were mostly preferred methods across the sample. The widely used risk analysis was the sensitivity analysis. In a seminal study of Brounen et al. (2004), four European countries viz., U.K., France, Germany and the Netherlands consisting of 313 companies during 2002 and 2003 were examined. Their result showed that $47 \%$ and $67 \%$ of the UK companies were used NPV and PB respectively as a primary tool for evaluating capital budgeting decision whereas companies in Netherlands were used $70 \%$ of NPV and $65 \%$ of PB methods. However, companies in France and Germany reported lower usages of both methods ( $42 \%$ for NPV, $50 \%$ for PB and 44\% for NPV, $51 \%$ for PB respectively). Previous studies have mainly conducted in the U.S. and the UK and 
limited number of studies are also available for the Netherlands (e.g., Herst, Poirters \& Spekreijse, 1997; Brounen et al., 2004).

Many researches recognized that DCF is the dominant in capital budgeting evaluation methods in the UK (e.g., Arnold \& Hatzopoulos, 2000), the USA (e.g., Ryan \& Ryan, 2002) and in Canada (e.g., Payne et al., 1999). However, most of the US firms use DCF techniques in comparison with firms in European countries (e.g., Brounen et al., 2004). There is still some reluctance in this field due to the technical aspects of DCF (e.g., Cary, 2008; Magni, 2009). In 1993, Bierman and Smidt opined that the DCF methods are the pre-eminent investment decision tool and thus, it is imperative to manager to learn about its uses. Anyhow, NPV, IRR and PB are the most popular methods among North American and Western European companies (Graham \& Harvey, 2001; Brounen et al., 2004).

Sekwat (1999) studied capital budgeting practices among 321 Tennessee municipal governments. His results showed that most of the municipal government's organizations are using benefit cost ratio $(62.5 \%)$ and payback methods (61.5\%), and financial officers were in reluctant using IRR, ARR and even NPV methods. Holmen (2005) conducted a survey of capital budgeting techniques, used for FDI's by Swedish firms and found that larger firms were preferred to use NPV and IRR methods. However, the most preferred method was the PB (79\%). In a survey of capital budgeting practices of Australian listed companies, Truong et al., 2008 found that NPV, IRR and PB were the most popular capital budgeting evaluation methods. Researchers were also identified the use of real option across the sample but not yet part of the mainstream.

In 2009, Kester and Robbins surveyed about capital budgeting techniques used by Irish listed companies. Results revealed that they use DCF methods and reported that most prevalent method was NPV, followed by PB, and IRR. Scenario analysis and sensitivity analyses were found to be most important tools for incorporating risk. WACC was the most important widespread method employed for calculating discount rate. On the other hand, Lazaridis (2004) studied capital budgeting practices in Cyprus. The PB was found as the most preferred method and not NPV.

Shinoda (2010) carried out a survey of capital budgeting in Japan. Questionnaire has been administered to collect data from a sample of 225 companies listed on Tokyo Stock Exchange. Results showed that firms were using combination of PB and NPV for evaluating capital investment projects.

In summary, many studies have found that increasing use of sophisticated capital budgeting techniques among many developed countries: US, UK, European and Australian companies (Freeman \& Hobbes, 1991;Shao \& Shao, 1996; Pike, 1996; Herst, Poirters \& Spekreijse, 1997; Brounen et al., 2004 ; Truong et al., 2008). However, US companies seem to be using more DCF methods as compared to European countries.

\subsection{Capital budgeting theory and practices in developing countries}

There is dearth of studies carried out on capital budgeting practices in developing countries during the last two decades. In comparison with developed countries, the results of the most studies show a different picture. In most of the developing countries, PB method was the dominant methods in evaluating capital investment. Kester et al.(1999) surveyed a total of 226 companies across six countries: Australia, Hong Kong, Indonesia, Malaysia, Philippines and Singapore. Results showed that PB is still important method and the DCF methods have become increasingly important. In five Asian countries, 95\% of firms used PB method and $88 \%$ of them use NPV in evaluating projects. However, both methods were treated as equally important. Kester et al. (1999) noted that sophistication of capital budgeting techniques within the developing countries in Asia has been increased very rapidly during the last decade.

Babu and Sharma (1996) studied Indian industries' capital budgeting practices and the findings showed that $90 \%$ of the companies were using capital budgeting methods. Of them $75 \%$ of companies reported that they were adopting DCF methods in evaluating capital budgeting, among them IRR was most popular. Sensitivity analysis was found to be popular in assessing risk. In 1998, Jain and Kumar studied about comparative capital budgeting practices: the Indian context and sampled 96 nongovernment companies where listed in Bombay Stock Exchange and five companies of South East Asia. They observed that most preferred capital budgeting techniques was the PB (80\% companies), followed by NPV and IRR. Sensitivity analysis was the preferred risk assessment method.

Cherukuri (1996) surveyed about capital budgeting practices: a comparative study of India and select South East Asian countries," with those of Hong Kong, Malaysia and Singapore and a sample consisted of top 300 non-government companies. This study found that of DCF methods, $51 \%$ of companies used IRR, followed by NPV (30\%). Of non DCF methods,PB (38\%) is the dominant method and the next widely used method was ARR (19\%). The non DCF methods were used as supplement to DCF methods. WACC is the widely used discount rate and Sensitivity analysis was mainly used for risk assessment. A recent survey of capital budgeting Practices in corporate India, conducted by Verma et al.(2009), took a sample of 30 manufacturing companies in India. The results confirmed findings of Cherukuri (1996).This study showed that most preferred method is IRR (56.7\%), followed by NPV (50\%) and PB (36.7\%).WACC $(43.3 \%)$ is the widely used discount rate and Sensitivity analysis (36.7\%) was mainly used for risk assessment. 
Researchers further observed that increasing adoption of DCF rather traditional use of non-discounted techniques. In 2012, Singh et al. studied on capital budgeting decision sampling from 31 listed companies in India. Albeit capital budgeting decision continued in India, all sampled firms reported that they are using DCF techniques in combining with non-DCF techniques. Of discounted cash flow techniques, more than three quarters of the sampled companies use IRR which more preferred than NPV that used by half of the sampled companies. Further it has been reported that half of the companies use real option techniques in selecting their capital investment projects. Long term capital is of financing source to finance fixed assets (net) and working capital (net) in India. Most of the variables are country specific; researchers call for further detailed research considering sectorial analysis of the constituent sectors of the sample companies would be shed new light on this area.

Hermes et al. (2007) carried out a comparative study of the Dutch and Chinese firms about capital budgeting practices. $66.7 \%$ of the Dutch CFOs stated that they used WACC and only $9.5 \%$ of them used PDCC. Small firms use CD most often $(22.7 \%)$ in comparison with larger firms (5.0\%). In the Dutch firms, $89 \%$ of CFOs reported that they used NPV methods however, $2 \%$ of CFOs stated that they used the ARR which is the least popular method. In contrast, $53.3 \%$ of Chinese firms indicated that they use WACC, and just $15.7 \%$ of CFOs of Chinese firms use PDCC. However, $28.9 \%$ of CFOs reported that they use CD which is higher than that of the Dutch counterparts. Chinese CFOs stated that they more likely to use NPV and PB methods ( $89 \%$ and $84 \%$ respectively) in evaluating capital budgeting projects. Thus, on average, Dutch CFOs use more sophisticated capital budgeting techniques than Chinese CFOs do.

In 2008, Leon et al. conducted a survey of capital budgeting practices of listed companies in Indonesia. DCF was mainly adopted methods in those companies as primary evaluation tool for capital investment projects. The most prevalent risk assessment tools were scenario and sensitivity analysis. Results supported that CAPM was not so popular

Recently, a survey of capital budgeting practices have been conducted by Khamees, Al-Fayoumi, and Al-Thuneibat (2010) in Jordan. Results reported that both DCF and non DCF method were still popular in evaluating capital budgeting investment. Surprisingly, the most popular method was PI, followed by PB.

Most recently, Maroyi and Poll (2012) conducted a survey of capital budgeting practices in listed mining companies in South Africa. Results showed that NPV, IRR and PB were the most prevalent methods in evaluating larger investment projects. Results further indicated that PB was found to be continual use of method. Following table summarizes the key findings on capital budgeting literature

Table 1. Key findings on capital budgeting studies during last two decades (from 1993 to 2013)

\begin{tabular}{|c|c|c|c|}
\hline Author/s & Population & $\begin{array}{l}\text { Most popular capital } \\
\text { budgeting method }\end{array}$ & $\begin{array}{l}\text { Methods for evaluating } \\
\text { risk in Capital Budgeting }\end{array}$ \\
\hline $\begin{array}{l}\text { Drury, Braund \& Tayles } \\
\text { (1993) }\end{array}$ & $\begin{array}{l}300 \mathrm{UK} \\
\text { Manufacturing } \\
\text { companies }\end{array}$ & PBP and IRR & Sensitivity analysis. \\
\hline Babu \& Sharma (1995) & $\begin{array}{l}73 \quad \text { Indian } \\
\text { companies }\end{array}$ & DCF Methods & $\begin{array}{l}\text { Sensitivity analysis and } \\
\text { adjustment of discount } \\
\text { rate methods }\end{array}$ \\
\hline $\begin{array}{lll}\text { Jog } & \& & \text { Srivastava } \\
(1995) & & \end{array}$ & $\begin{array}{l}582 \text { Canadian } \\
\text { companies }\end{array}$ & IRR and PBP & Sensitivity analysis \\
\hline Pike (1996) & $\begin{array}{l}\text { Large } \\
\text { companies }\end{array}$ & PBP & \\
\hline Kester \& Chang (1996) & 54 companies & IRR and PBP & $\begin{array}{l}\text { Scenario and sensitivity } \\
\text { analysis }\end{array}$ \\
\hline $\begin{array}{l}\text { Farragher, Kleiman \& } \\
\text { Sahu (1999) }\end{array}$ & $\begin{array}{l}379 \text { US } \\
\text { companies in the } \\
\text { Standard \& Poor's } \\
\text { industrial index }\end{array}$ & DCF Methods : NPV & $\begin{array}{l}\text { Capital Assets Pricing } \\
\text { Model }\end{array}$ \\
\hline Sekwat (1999) & $\begin{array}{l}166 \quad \text { Finance } \\
\text { Officers } \\
\text { Municipal } \\
\text { Governments }\end{array}$ & $\begin{array}{l}\text { Cost-Benefit Ratio and } \\
\text { PBP }\end{array}$ & \\
\hline
\end{tabular}


(Tennessee)

Kester , Chang, Echanis, Haikal, . Isa, Skully, Tsui, \& , Wang (1999)

Arnold \& Hatzopoulos
(2000)

Hall (2000)

Graham \& Harvey

(2001)

Ryan \& Ryan (2002) 1997

392 Chief

CFOs U.S.
226 companies in Australia, Hong Kong, Indonesia, Malaysia, The Philippines and Singapore in 1996-

300 UK Companies 65 Respondents (South Africa) of companies in the

205US Companies

129 Swedish PBP

Corporations

Lord, Shanahan \& Boyd (2004)

Brounen, deJong \& Koedijk (2004)

Lazaridis (2004)

Elumilade, Asaolu \& Ologunde (2006)

Lam, Wang \& Lam (2007)

Small Medium Sized Companies (Cyprus)

29 Local authorities of New Zealand Local Government

Four European countries viz., U.K., France, Germany and the Netherlands consisting of 313 companies during 2002 and 2003

94 firms from Nigerian stock exchange (Nigeria)

157 Hong Kong

Building

Contractors

Dedi \& Orsag (2007)
NPV and IRR

Equal importance to discounted and non-discounted cash flow techniques in evaluating projects

DCF is widely using by the selected UK firms.

IRR

NPV and IRR

Large firms- risk adjusted discount rate Small firmsMonte Carlo Simulation

Sensitivity analysis, Scenario analysis, inflation adjusted cash flows, economic value added, and incremental IRR

Annuity

\section{Cost Benefit Ratio}

Primary tools were in UK - NPV and PBP, in Netherland - NPV and PBP , France and Germany reported lower usages of both methods (42\% for NPV, $50 \%$ for $\mathrm{PB}$ and $44 \%$ for NPV, $51 \%$ for $\mathrm{PB}$ respectively).

PBP

PBP, ARR, and NPV

PBP and Average Shortening Payback Accounting Rate of Period, Raising Required Return

IRR, PBP (cost of capital is calculated by WACC)
Statistical Risk Analysis, Scenario Analysis

Linear programming Rate of Return

Risk-adjusted discount rate, Certainty equivalents for cash flows selected from 400 of the best Croatian firms \& 34 banks 
from a ranking of

Croatian

banks

Truong, Partington \& 87 Australian companies
NPV, IRR and PBP

Listed DCF Techniques

Leon,

Isa \& Kester

Shinoda (2010) Marchant (2010)
2008

Zubairi (2008)

Verma, Gupta \& Batra (2009)

Hall \& Millard (2010)

Poudel, Sugimoto, Yamamoto, Nishiwaki, \& Kano (2010)

Bennouna,Meredith \&

229

Companies

(Indonesia)

35 firms listed on KSE (Pakistan)

100 manufacturing companies (India)

\section{South African IRR} industrial

companies listed

on the JSE

Securities

Exchange for at

Least ten years.

Dragota. Tatu, ,Pele, Vintila, \& Semenescu (2010)

Professors in the economic field, having competences in Corporate Finance and teaching in Romania.

225 firms listed on the Tokyo Stock Exchange

50 Farms (Nepal)

88 Large Firms
NPV, IRR or PI, Discount Rate used for the investment projects analysis is the weighted average cost of capital.

PBP and NPV

Benefit-Cost ratio $(\mathrm{B} / \mathrm{C})$, NPV, IRR, and PBP

Trends

towards sophisticated techniques (DCF) have continued. Of those which did, the
Real options techniques have gained a foothold in capital budgeting but are not yet part of the mainstream. Capital Assets Pricing Model is found to be the most popular method used in the estimation of the cost of equity capital

Scenario and Sensitivity

Analysis

Weighted Average Cost of Capital (WACC) was to calculate the Cost of Capital. Sensitivity' analysis

Sensitivity Analysis , Monte Carlo Method and the Scenarios Technique 


$\begin{array}{ll}\text { Kester } \quad \& \quad \text { Robbins } & 18 \text { Chief Financial } \\ \text { Officers of } \\ \text { companies listed } \\ \text { on the Irish Stock } \\ \text { Exchange }\end{array}$

Singh, Jain \& Yadav 31 listed (2012)

Maroyi \& Pol 1 (2012)
Companies (India)

13 Companies

Listed in the

Mining Sector of

the Johannesburg

Securities

Exchange (JSE). majority favored NPV and IRR.

scenario analysis and risk-adjusted discount rate. Use of real options is limited (8\%).

More $\quad$ Sophisticated

Discounted Cash Flow

Scenario Analysis and

Sensitivity Analysis

(Weighted Average Cost of Capital is to evaluate all proposed capital investments).

More sophisticated DCF Sensitivity analysis techniques.

NPV

Real option

\section{Source: Survey data}

\subsection{Factor affecting capital budgeting}

In practice, there are numerous factors that heavily influence on capital budgeting decision. Behavioral finance become increasingly important and intrudes into capital budgeting theory, and the knowledge on behavioral finance derived from sociology and psychology. The behavioral finance states that capital investment decision is not solely dependent on quantitative data, but the decision is also strongly influenced by qualitative data including institution and personal values, tolerance to risk, situational context and so on. More recently, Ben-David, Graham, and Harvey's (2008) study of CFOs found that overconfidence was a key driver of investment, however optimism found to be more marginal effect on investment. Larrick, Burson, and Soll (2007) found that the degree of individuals overconfident is strongly associated with their thinking that make them to feel that they are better than average. Overconfident managers generally prefer to overinvest and the overconfident tends to attract more mergers, starting new firms and initiate more investment. Similarly, Brown and Sarma (2007) stated that CEO overconfidence affect the frequency of corporate acquisitions of a firm. If past returns on investment are high, CFOs would become more confident on their estimate of future returns. A group of 55 managers working in small firms of computer industry have been studied by Simon and Houghton (2003). Findings showed that managers with greater overconfidence would prefer to introduce more risky products and seem to fail many times. In early 1990s, some studies found that managerial overconfidence tends to innovation (Staw, 1991) and to plant expansion (Nutt, 1993). Glaser, Schafers, and Weber (2008) surveyed senior managers behavior and they observed that when managers are optimistic, they increase their exposure to firm specific risk when transaction on invest more and in turn increase investment cash flow sensitivity.

Size of the firm is one of the major determinants in capital budgeting practices (e.g., Ho \& Pike, 1992; Graham \& Harvey, 2001; Farragher et al., 2001; Brounen et al., 2004; Verbeeten, 2006). Researches supported that large firms adopts more innovative capital budgeting methods, say, sophisticated capital budgeting practices, to a large extent than smaller firms do (e.g., Rogers, 1995; Williams \& Seaman, 2001) since the larger firms have the capacity and resources to use sophisticated capital budgeting practices (Ho \& Pike, 1992). Payne et al.(1999) and Ryan and Ryan (2002) documented that large firms were more inclined to use more sophisticated capital budgeting practices. This is due to the larger firms involves larger projects and the use of sophisticated capital budgeting practices become less costly (Payne et al., 1999; Hermes et al., 2007).There was a positive relationship between firm size and the use of DCF methods. Findings have also been confirmed in Hermes et al.'s (2007) studies. Trahan and Gitman (1995) connotes that large companies exploited DCF methods ( $88 \%$ for NPV and $91 \%$ IRR) than small companies (65\% for NPV and 54\% for IRR). It was further confirmed in Segelod's (1998) study and he found that major firms uses PB model for evaluating small investments, however, for the large investment decision at least of the DCF methods is in practice. In 2001, Graham and Harvey studied about capital budgeting methods and firm size in the U.S. and results showed that there is a significant negative relationship between size and PB. Brounen et al.(2004) found that company size was positively correlated with the use of capital budgeting methods, large companies use NPV, IRR, and sensitivity analysis more than small companies. 
Generally, ownership structure has greater influence on any managerial decision making and resultant effect on firm's performance (Warfield,Wild \& Wild, 1995; Klassen, 1997). Greater managerial ownership has been identified to be increased use of recommended capital budgeting methods and thus less likely to experience financial distress (Donker, Santen \& Zahir, 2009). It is oft-reported that what managers actually do they ignore profitability investment (even if it offers positive NPV), if accounting rate of return is too low, and thus top management willed to sacrifice long term value to meet accounting targets (Graham, Harvey \& Rajgopal, 2005).The ownership sometime classify as listed at the stock exchange or non listed (Hermes et al., 2007). Listed firms were used accurate estimation of cost of equity ,and cost of capital and more likely to NPV or IRR than non listed (Hermes et al., 2007).

Nature of the industries were also identified as the determinant of capital budgeting practices, for example financial services industry and the building, construction and utilities industries, have been interest of using more sophisticated capital budgeting practices than other industries (Verbeeten, 2006). Further, many empirical researches in the past showed that capital budgeting practices are different across industries (e.g., Ho \& Pike, 1998). For example, widespread use of real option or game theory are more prevalent in the pharmaceutical industry (e.g., Bowman \& Moskowitz, 2001; McGrath \& Nerkar, 2004), the extraction industry (e.g., Trigeorgis, 1993), and the financial services industry and the high-tech industry (e.g., Billington, Johnson \& Triantis, 2003).

Education of CFOs was recognized as the determinant of capital budgeting. There was a general argument that CFO with higher education has fewer problems in understanding more sophisticated capital budgeting techniques and they thus have the capacity to use them. For example, in Chinese firms, CFOs with higher level of education use cost of debt less often in comparison with less educated CFOs. Thus, a positive relationship identified between educational background of CFOs and the use of sophisticated methods (Hermes et al., 2007). Among the U.S. sample, there was a positive association has been found between CEO education and use of IRR (Graham \& Harvey, 2001) and the findings has been confirmed in the Netherlands, Germany and France, but not in the UK (Brounen et al., 2004). The reasons for more widespread use of DCF are the availability of computer software that used in computation (e.g., Pike, 1996) and increased level of formal education of managers (e.g., Pike, 1996; Sangster, 1993). A few studies found that age of the CFOs was also a determinant of capital budgeting methods. For example, older CFOs could be reluctant to adopt new techniques, and instead prefer to relaying on older methods (e.g., Hermes et al., 2007).

Since capital investment involves in long term, uncertainty /risk would play a vital role in capital investment decision making. Generally, uncertainty refers to as the gap between information available and information required to make any decision. Complete information is unavailable in long run and thus, uncertainty is the dominant factor in capital investment (Simerly \& Li, 2000; Zhu \& Weyant, 2003). Nature and type of uncertainty could be, including raw material uncertainties, input market uncertainties, labor uncertainties, political uncertainties, production uncertainties, output market uncertainties, liability uncertainties, interest uncertainties, inflation uncertainties, policy uncertainties, exchange rate uncertainties, competitive uncertainties and society uncertainties. Uncertainties have been treated with adopting sophisticated capital budgeting practices, for example, use of ROR and/or GT tools (e.g., Bowman \& Hurry, 1993; Zhu \& Weyant, 2003). The main concepts of the ROR demonstrates that specific uncertainties (rather than in general) that would affect capital budgeting practices (Dixit \& Pindyck, 1994). Game theory specifies that the optimal investment criterion can also be changed by specific uncertainties (Smit, 2003). Thus, specific uncertainties need to be tackled with using different capital budgeting methods. The research findings supported that sophisticated capital budgeting practices are crucial and useful if financial uncertainties i.e., exchange rate, interest exist. However, social uncertainties, market uncertainties, and input uncertainties have not sufficiently supported to influence on use of sophisticated capital budgeting practices. Rather, theoretical background, many experts in capital budgeting area is expected to offer the capacity and willingness to adopt contemporary capital budgeting practices (e.g., Libby \& Waterhouse, 1996, Williams \& Seaman, 2001). Theory and a few empirical research states that specific uncertainties affect capital budgeting practices, for example, Ho and Pike (1998) found that there is a positive relationship between socioeconomic uncertainty (i.e., governmental regulations, trade unions actions) and the application of risk analysis techniques, however, the empirical evidence on these relationship with sophisticated capital budgeting practices are scarce (Verbeeten, 2006).

Recognition, assessment and reflection of the risk/uncertainty are intriguing. Nowadays, there are number of risk analysis method available such as sensitivity analysis, scenario analysis, decision trees, computer simulation and Monte Carlo analysis. In Graham and Harvey's (2001) study, participants recognized market risk and they also reported other risk factors including interest rate, inflation, size, foreign exchange rate. Surprisingly, they found that at least half of the firm did nothing to adjust WACC (firm's average risk) to incorporate project risk. However, in 1996, Shao and Shao reported that firms employed more on risk adjusted cash flows than risk-adjusted discount rates. Across their sample, they found that sensitivity analysis was the principal assessment technique. In contrast, Gitman and Vandenberg (2000) found in their study that $39 \%$ of firms were adjusting their rates against adjusting risk for cash flows. Through there are number of sophisticated risk analysis models available, the applicability of those models were prone to barriers. The 
reasons for their reluctant have been reported as; it is not practical, depending on unrealistic assumption, difficulties in explaining to the top management and the difficulties in applying (Trahan \& Gitman, 1995). Notwithstanding progress in risk identification, assessment and adjustment has been reported, none of the studies have not been looked at actual risk analysis, its process and management inputs to improve or usage of existing risk assessment and adjustment models. Sophisticated capital budgeting practices would help to identify many different types of investment projects in terms of uncertainty.A range of risk across the many investment projects would create diversification. Diversification generally helps to maximize the income from investments at minimum risk. A positive relationship has been found between diversification and use of sophisticated capital budgeting practices (Verbeeten, 2006). Recently, Holmen and Pramborg (2009) reported that the use of payback method has been positively combined with political risk.

Klammer (1993), and Shank and Govindarajan (1992) suggested that nonfinancial consideration have been integrated into capital budgeting practices. For example, corporate management integrated into capital budgeting and thus the decision depends on some of the strategic management tools such as value chain analysis, cost drivers analysis, and completive advantage analysis. According to Carr and Tomkins (1996), the most successful companies were found to be using nonfinancial strategic information in making investment decision among their sample of 51 case studies in the UK, the U.S., and the German companies. However, it is argued that nonfinancial methods were prevalence when the firms did not adequately implement DCF methods (Carr \&Tomkins 1996). However, any studies have not been carried out the use of non financial methods linking to DCF analysis. It has been argued that increasing acceptance of DCF analysis ignores the use of nonfinancial methods (e.g., Graham \& Harvey 2001; Ryan \&d Ryan, 2002).

Capital budgeting practices are different and may have "country effect" influence. This can be attributed to the some level of economic factors that determine choice of capital budgeting practices. It is recommend furthering research in indentifying country effect on capital budgeting practices with respect to the level of economic, human, financial and technological improvement. Shahrokh (2002) argued that capital budgeting is very complex, determined by many factors including: terminal values, foreign currency fluctuations, long-term inflation rates, subsidized financing, and Political risk. In Sekwat's (1999) study of capital budgeting practices in Tennessee municipal governments, the decision in using capital budgeting techniques are based on simple, versatile and flexibility of those techniques. Notwithstanding, he further argued that the usage of techniques in practices is in conjunction with qualitative factors such as ethical, legal, or political considerations. He concluded that since government funds the capital projects, political factors plays a critical role in making capital investment decisions.

\subsection{Disparities between capital budgeting theory and practices}

Capital budgeting theory recommends in using DCF methods (NPV, IRR, MIRR, PI and DPB) and non DFC methods (PB and ARR) for making capital budgeting decision. However, all most all the firms in developed and developing countries inclined to use sophisticated capital budgeting methods along with many capital budgeting tools for incorporating risk (i.e., sensitivity analysis, real options) and sophisticated discounted rate (i.e., Weighted Average Cost of Capital, Cost of Debt, CAPM) (e.g., Arnold \& Hatzopoulos, 2000; Graham \& Harvey, 2001; Ryan \& Ryan, 2002; Cooper et al., 2002; Brounen et al., 2004; Hermes et al.,2007; Bennouna et al., 2010; Maquieira, Preve and Allende, 2012).

Nemours factors have been identified as the determinant of capital budgeting during the last two decades including size of the firm, ownership structure, nature of industries, educational qualification of CFOs, experience of CFOs, age of CFOs, uncertainty(for example, interest rate, inflation, foreign exchange rate), nonfinancial consideration and other factors (i.e, economic, human, technology, finance, ethical and political). Among them, some factors (for example, size of the firm, educational qualification of CFOs, experience of CFOs, age of CFOs) were positively associated with the use of sophisticated capital budgeting practices. However, in some cases, economic, political and technological factors directly and indirectly affect choice of the capital budgeting practices. (e.g., Bowman \& Moskowitz, 2001; Zhu \& Weyant, 2003; McGrath \& Nerkar, 2004; Verbeeten, 2006; Donker et al., 2009). Moreover, the factors determining capital budgeting practice connotes that to certain extent capital budgeting practice prone to 'country effect influence', for example economic factor, cutting edge technology (i.e., decision support system), political factors, accounting policies, accounting standards and other infrastructure facilities. Although capital budgeting theory was applicable regardless of countries, to certain extent the actual practices of capital budgeting (for example selection of capital investment) vary (e.g., Graham \& Harvey, 2001; Shahrokh ,2002).'In practice uncertainty, information asymmetry, multiple (conflicting) objectives, real options and multi -period multi project considerations greatly complicate capital budgeting beyond the focus of the theory' (Arnold \& Hatzopoulos, 2000, p.609). A consideration of the impact of information asymmetry, real options and other complications on the capital budgeting exercise gives one the view that there is no unique correct technique and that there is a need for multiple methods (Arnold \& Hatzopoulos, 2000). Thus, all these factors impinge on choice of the capital budgeting practices, and consequently, there are disparities between theory and practices. 
Studies on the practice of capital budgeting in many countries have found that firms increasingly employ more sophisticated capital budgeting techniques to make investment decisions over several years (Klammer, 1973; Klammer \& Walker, 1984; Pike, 1988; Klammer, Koch \& Wilner, 1991; Jog \& Srivastava, 1995; Gilbert \& Reichart, 1995; Farragher et al., 1999;Arnold \& Hatzopoulos, 2000; Graham \& Harvey, 2001; Mustapha \& Mooi, 2001; Ryan \& Ryan, 2002; Brounen et al., 2004; Hermes et al., 2007; Truong et al., 2008; Baker et al., 2011; Singh et al., 2012). When comparing a developed economy with an emerging economy, the developed economy has highly developed capital markets with high levels of liquidity, meaningful regulatory bodies, large market capitalization, and high levels of per capita income (Geary, 2012). An emerging market is in the process of rapid growth and development with lower per capita income, less mature capital markets and very small capital projects, compared with developed countries. Therefore, obviously, emerging market economies pose challenges in applying capital budgeting techniques, owing to less developed capital markets and the difficulty of setting key parameters.

\subsection{Answering to the research questions: Summary of the findings}

It is crucial to answer the research questions in order to attain research aims. The first question enquired about "what are the capital budgeting theories and practices used by firms? Are there any disparities between the capital budgeting theories and practices? If so how?" The answers for these questions have been well documented during the last twenty years of studies. Capital budgeting theory recommends in using DCF methods (NPV, IRR, MIRR, and DPB) and non DFC methods (PB and ARR) for making capital budgeting decision. However, all most all the firms in developed and developing countries inclined to use sophisticated capital budgeting methods along with many capital budgeting tools for incorporating risk (i.e., sensitivity analysis, real options) and sophisticated discounted rate (i.e., WACC, CD, CAPM) (e.g., Arnold \& Hatzopoulos, 2000; Graham \& Harvey, 2001; Ryan \& Ryan, 2002; Cooper et al., 2002; Brounen et al., 2004; Hermes et al., 2007; Bennouna et al., 2010; Maquieira et al., 2012). Thus it can be concluded that there are some disparities between capital budgeting theory and practice. The next research's question further backs up to this question.

The second question asked about "what are the factors determines the use of capital budgeting practices? Are there different across countries? If so how?" Nemours factors have been identified as the determinant of capital budgeting during the last two decades including size of the firm, ownership structure, nature of industries, educational qualification of CFOs, experience of CFOs, age of CFOs, uncertainty(for example, interest rate, inflation, foreign exchange rate), nonfinancial consideration and other factors (i.e, economic, human, technology, finance, ethical and political). Among them, some factors (for example, size of the firm, educational qualification of CFOs, experience of CFOs, age of CFOs) were positively associated with the use of sophisticated capital budgeting practices. However, in some cases, economic, political and technological factors directly and indirectly affect choice of the capital budgeting practices. (e.g., Bowman \& Moskowitz, 2001; Zhu \& Weyant, 2003; McGrath \& Nerkar, 2004; Verbeeten, 2006; Donker et al.,2009). Moreover, the factors determining capital budgeting practice connotes that to certain extent capital budgeting practice prone to "country effect influence", for example economic factor, cutting edge technology (i.e., decision support system), political factors, accounting policies, accounting standards and other infrastructure facilities. Although capital budgeting theory was applicable regardless of countries, to certain extent the actual practices of capital budgeting (for example selection of capital investment) vary (e.g., Graham \& Harvey, 2001; Shahrokh , 2002). Thus, all these factors impinge on choice of the capital budgeting practices, and consequently, there are disparities between theory and practices.

The last question asked about "what are the gaps in the existing capital budgeting literature?" Traditional financial theory suggests that the decision makers are rational, however, modern theory suggests that decision have influenced by many cognitive illusions (Leon et al., 2008; Tayib \& Hussin, 2011). Thus behavioral finance came into play in capital budgeting decision making. Capital budgeting research connected with behavioral finance have not been studied any developing countries during the last twenty years. Literature says behavioral finance is a dominant theory determining capital budgeting decision, confirmed in many studies carried out in developed countries. Thus, there is a complete dearth of research in Asian studies in case of behavioral finance penetration on capital budgeting practices.

No studies have been attempted to identify relationship between supportive capital information system (software products to make the required analysis easier in comparison with manual system) and capital budgeting decision making. Thus it has been identified as a gap between information system and choice and practice of capital budgeting (Bennouna et al., 2010). Similarly, the environment in which organization are working impact on quality decision. Thus, researcher should concentrate on scanning organizational environment to make good investment decision rather purely depends on financial theory. Thus it is paramount important in the current context.

Almost all the research carried out during the last two decades adopted limited methodological aspects. For example, cross sectional research design, case study and some form of qualitative study were more popular (e.g., Butler et al., 1993; Verbeeten, 2006; Hermes et al.,2007; Maquieira et al., 2012). However, in modern world, some form of event 
study methodology would be seminal for providing greater insights into capital budgeting practices. Thus, a gap has been identified in use of methodological concepts.

Renowned researchers found that nowadays most of the large companies are inclined to use sophisticated capital budgeting practices. However, it is intriguing question whether SCBP are important to all types of investment (e.g. expansion, replacements, mergers and takeovers) and all type of industries, and those techniques outperform than non SCBP. Thus, these conundrums need to be well investigated.

Many research scholars have argued that capital budgeting influenced by "country effect influence" (e.g., Graham \& Harvey, 2001; Shahrokh, 2002; Hermes et al., 2007), for example, economic policies, taxation system, accounting policies, conductive social climate, culture of people, technological factor (i.e., decision support system), government control, political factors, infrastructure facilities. Therefore, more extensive studies are imperative from unsearched countries to build robust knowledge.

Many studies conducted in developed counties have found that firms use more sophisticated capital budgeting practices (Graham \& Harvey, 2001; Brounen et al.,2004). Nonetheless, when comparing with developed countries, more sophisticated capital budgeting practices are not prevalent in developing countries. Thus, future research scholars need to consider the challenges faced by CFOs with regard to the use of sophisticated capital budgeting practices (i.e. organizational barriers/knowledge gap of CFOs, technological challenges) as they lead to increased performance.

Another opportunity for future research is the investigation of other organizational characteristics (e.g. business unit strategies, reward and incentive structures, distribution of decision rights and financial structure) that have been shown to affect capital budgeting practices. Renowned researchers have found that nowadays, most large companies are inclined to use sophisticated capital budgeting practices (SCBP).

\subsection{Policy recommendation}

Many research scholars criticized that many researches on capital budgeting were opt-testing the methods of capital budgeting and its practices. They were purely finding that actual what methods were in practice. However, in practice, there are enormous factors affecting the capital budgeting practice and it has "country effect" too. In line up with this argument, this research was well thought out in its design and become springboard for future research. This study contributed by stating the known and unknown arena of capital budgeting during the last two decades.

In the cutting edge technology world, the way of doing things have been changed and challenging. For example, decision support system become more prevent in making decision and more advanced technological sphere penetrates into assessing capital budgeting practices than ever before. Thus, this research would make awareness to top management, policy makers, practitioners and stakeholders of the company.

\section{References}

Alkaraan, F., \& Northcott, D. (2006). Strategic capital investment decision-making: A role for emergent analysis tools?: A study of practice in large UK manufacturing companies, The British Accounting Review, 38(2),149-173.http://dx. doi:10.1016/j.bar.2005.10.003

Allen ,F., \& Morris, S. (1998). Finance applications of game theory, the working paper series, Alfred P.Sloan foundation, $1-45$

Amram, M., \& Howe, K.M. (2002).Capturing the value of flexibility, Strategic Finance, 84(6), 10-13.

Andrés, P.de, Fuente, G.de., \& Martín, P. S. (2015).Capital budgeting practices in Spain, BRQ Business Research Quarterly, 18(1), 37-56.http://dx.doi:10.1016/j.brq.2014.08.002

Arnold, G. C., \& Hatzopoulos, P. D. (2000).The theory-practice gap in capital budgeting: evidence from the United Kingdom, Journal of Business Finance and Accounting, 10(5), 603-626. http://dx.doi.org/10.1111/1468-5957.00327

Atkeson, A., \& Cole, H. (2005). A Dynamic Theory of Optimal Capital Structure and Executive Compensation, working paper, NBER 11083.

Atrill, P.(2009). Financial management for decision makers, 5th edn., England: FT Prentice Hall.

Babu, C. P., \& Sharma, A. (1995). Capital Budgeting Practices in Indian Industry-An Empirical Study, ASCI Journal of Management, 25(1), 34-43.

Bennouna, K., Meredith,G. G., \& Marchant, T. (2010). Improved capital budgeting decision making: evidence from Canada, Management Decision, 48(2), 225-247. http://dx.doi.org/10.1108/00251741011022590

Bierman, H. (1993). Capital Budgeting in 1992: A Survey, Financial Management, 22(3), 24-24. http://dx.doi.org/10.2307/3665921 
Billington, C., Johnson, B., \& Triantis, A. (2003).A real options perspective on supply chain management in high technology, Journal of Applied Corporate $\quad$ Finance, 15(2), 43.http://dx.doi.org/10.1111/j.1745-6622.2002.tb00693.x

Black, F., \& Scholes, M. (1973).The pricing of options and corporate liabilities, The Journal of Political Economics, 81(3), 637-654. http://dx.doi.org/10.1086/260062

Blaikie, N. (2007). Approaches to social enquiry, 2nd edn. Cambridge: Polity Press.

Block, S. (2007).Are real options actually used in the real world?. The Engineering Economist, 52(3), $255-267$. http://dx.doi:10.1080/00137910701503910

Bock, K., \& Truck, S. (2011).'Assessing uncertainty and risk in public sector investment projects', Technology and Investment, 2(2),105-123. http://dx.doi:10.4236/ti.2011.22011

Bornholt, G.(2013).The failure of the Capital Assets Pricing Model (CAPM): An update and Discussion, ABACUS: A Journal of Accounting, Finance and Business Studies, 49(supplement), 36-43. http://dx.doi.org/10.1111/j.1467-6281.2012.00382.x

Bowman, E. H., \& Hurry, D. (1993).Strategy through the option lens: an integrated view of resource investments and the incremental choice process, Academy of Management Review, 18(4), 760-782. http://dx.doi.org/10.5465/AMR.1993.9402210157

Bowman, E. H., \& Moskowitz, G. T.( 2001). Real options analysis and strategic decision making, Organizations Science ,12(6),772-777. http://dx.doi.org/10.1287/orsc.12.6.772.10080

Brealey, R. A., \& Myers, S. C. (2003). Principles of Corporate Finance (International Edition), 7th edn., New York: McGraw-Hill.

Brennan, M. J., \& Schwartz, E. S. (1992). A new approach to evaluating natural resource investments. In: Stern, J.M., Chew, D.H. (Eds.), The Revolution in Corporate Finance, 2nd edn, Oxford, UK, Blackwell Publishers, , $107-117$.

Brickley. S. Z. (2006).Managerial Economics and Organizational Architecture, 3rd edn., China: McGraw-Hill.

Brigham, E. F., \& Ehrhardt, M. C. (2002). Financial Management: Theory and Practice,10th edn.,Ohio, Thomson/South-Western.

Brounen, D., de Jong, A., \& Koedijk, K. (2004). Corporate finance in Europe: Confronting theory with practice, Financial Management, 33(4),71-101.

Brown, R., \& Sarma, N.(2007). CEO Overconfidence, CEO Dominance and Corporate Acquisitions, Journal of Economics and Business,59(5),358-379. http://dx. doi:10.1016/j.jeconbus.2007.04.002

Bryman, A., \& Bell, E. (2011). Business research methods. 3rd edn. United Kingdom: Oxford University press.

Busby, J. S., \& Pitts, C. G. C. (1997). 'Real options in practice: an exploratory survey of how finance officers deal with flexibility in capital appraisal', Management Accounting Research, 8(2), 169-186. http://dx. doi:10.1006/mare.1996.0040

Byrne, J. P., \& Davis, E. P. (2005).Investment and Uncertainty in the G7, Review of World Economics, 141(1), 1-32. http://dx.doi: 10.1007/s10290-005-0013-0

Carr, C., \& Tomkins, C. (1996). Strategic investment decisions: the importance of SCM. A comparative analysis of 51 case studies in UK, US. and German companies, Management Accounting Research, 7, 199-217.

Cary, D. (2008). An integrated approach to alternative capital budgeting techniques, mutually exclusive projects, and consistency with the net present value rule, Journal of American Academy of Business, 13(2), 14-19.

Chadwell-Hatfield, P., Bernard,G., Philip,H., \& Allen,W. (1997). Financial Criteria, Capital Budgeting Techniques, and Risk Analysis of Manufacturing Firms, Journal of Applied Business Research, 13(1), 95-104. http://dx.doi.org/10.19030/jabr.v13i1.5775

Chatterjee, S., Wiseman, R. M., Fiegenbaum, A., \& Devers, C. E.(2003).Integrating behavioral and economic concepts of risk into strategic management: the Twain Shall meet, Long Range Planning. 36, 61-79. http://dx.doi:10.1016/S0024-6301(02)00201-7

Cherukuri, U, R. (1996).Capital Budgeting Practices: A Comparative Study of India and Select South East Asian Countries, ASCI Journal of Management, 25(2), 30-46.

Cho, D. (1996).An alternative and practical theory of capital budgeting: Stockholder wealth maximization approach, The Mid - Atlantic Journal of Business, 32(2), 93-104 
Cooper, W. D., Morgan, R. G., Redman,A., \& Smith, M. (2002). Capital Budgeting Models: Theory vs. Practice, Business Forum, 26(1\& 2),15-19.

Copeland, T. E., \& Weston, J. F. (1992). Financial Theory and Corporate Policy, 3rd edn. Reading: Addison-Wesley Publishing Company Inc.

Corbin, J., \& Strauss, A. (1990).Grounded theory research: Procedures, canons, and evaluative criteria, Qualitative Sociology, 13, 3-21. http://dx.doi.org/10.1007/BF00988593

Cuthbertson, K., \& Nitzsche,D.(2008). Investments, 2nd edn., England: John wiley \& sons ltd.

Daunfeldt ,S., \& Hartwig,F. (2011). What determines the use of the capital budgeting methods? Evidence from Swedish listed companies, Available at:

www.hui.se/MediaBinaryLoader.axd?MediaArchive_FileID=17edc3a8-0911-4613-813e-fdf1ce965da0\&FileName =HUIwp57.pdf\&MediaArchive_ForceDownload=true (Accessed $: 28$ April 2012).

Dayananda, D., Irons, R., Harrison, S., Herbohn, J., \& Rowland, P. (2002).Capital Budgeting: Financial Appraisal of Investment Projects, Edinburgh: Cambridge University Press.

Dickerson, P. J. (1963).Capital Budgeting- Theory and Practice, California Management Review, 53-60. http://dx.doi.org/10.1080/00137918408902894

Dixit, A. K., \& Pindyck, R. S. (1994). Investment under Uncertainty, Princeton, New Jersey: Princeton University Press,.

Donker, H., Santen, B., \& Zahir, S. (2009).Ownership structure and the likelihood of financial distress in the Netherlands, Applied Financial Economics, 19(21), 1687-1696. http://dx.doi.org/10.1080/09603100802599647

Dragota,V., Tatu,L., Pele, D., Vintila, N., \& Semenescu, A.(2010).Capital Budgeting: The Romanian University Professors' Points of View, The Review of Finance and Banking, 2(2),95-102.

Drury, C., Braund, S., \& Tayles, M. (1993).A Survey of Management Accounting Practices in UK Manufacturing Companies, ACCA Research Paper, 32, Chartered Association of Certified Accountants. http://hdl.handle.net/10068/480017

Easterby-Smith, M., Thorpe, R., \& Lowe, A. (2002).Management Research an Introduction. 2nd edn. Thousand Oaks: Sage Publications.

Ekeha, G. E. (2011).Capital budgeting practices and economic development: A comparative study of companies in Western Europe and West Africa. Available at http:// www.amazon.com/Capital-Budgeting-Pratices-Economic Development/dp/3844382593 (Accessed : 15.03.2011)

Emmanuel, C., Otley,D., \& Merchant, K.(1995). Accounting for Management Control - 2nd edn, London: International Thomson Business Press.

Emmanuel, C., Harris, E., \& Komakech, S. (2010).Towards a better understanding of capital investment decisions, Journal of Accounting and organizational change, 6(4),477-504. http://dx.doi.org/10.1108/18325911011091837

Fama, E. (1970).Efficient Capital Market: A Review of Theory and Empirical Work, Journal of Finance, 25, 382-417. http://dx.doi.org/ 10.1111/j.1540-6261.1970.tb00518.x

Farragher, E. J., Kleiman, R. T., \& Sahu, A. P. (1999). Current Capital Investment Practices, The Engineering Economist, 44(2),137 -150.http://dx.doi:10.1080/00137919908967513

Farragher, E. J., Kleiman, R. T., \& Sahu, A. P. (2001).The association between the use of sophisticated capital budgeting practices and corporate performance, The Engineering Economist, 46(4), 300-311. http://dx.doi:10.1080/00137910108967579

Freeman, M., \& Hobbes, G. (1991).Capital Budgeting: Theory versus Practice, Australian Accountant, 61(8), 36-41. http://dx.doi:10.1080/00137918408902894

Galbraith, J. (1973). Designing Complex Organizations, Reading: Addison-Wesley.

Ghahremani, M., Aghaie, A., \& Abedzadeh, M. (2012).Capital Budgeting Technique Selection through Four Decades: With a Great Focus on Real Option, International Journal of Business and Management, 7(17). http://dx.doi.org/10.5539/ijbm.v7n17p98

Gitman, L. J., \& Vandenberg, P. A. (2000). Cost of capital techniques used by major US firms: 1997 vs. 1980, Financial Practice and Education, 10(2), 53-68.

Glaser, M., Schäfers,P., \& Weber, M. (2008).Managerial Optimism and Corporate Investment: Is the CEO Alone Responsible for the Relation? Working Paper, University of Mannheim. http://dx.doi.org/10.2139/ssrn.967649 
Graham, J., \& Harvey, C. (2001).The theory and practice of corporate finance: evidence from the field, Journal of Financial Economics, 60(2/3),187-243. http://dx.doi:10.1016/S0304-405X(01)00044-7

Graham, J. R., Harvey, C. R., \& Rajgopal, S.(2005).The economic implications of corporate financial reportin', Journal of Accounting and Economics,40(1-3),3-73 http://dx.doi:10.1016/j.jacceco.2005.01.002.

Haka, S. F. (1987).Capital Budgeting Techniques and Firm Specific Contingencies: A Correlational Analysis, Accounting, Organizations and Society, 12(1),31-48. http://dx.doi:10.1016/0361-3682(87)90014-6

Haka,S.F., Gordon,L.A., \& Pinches,G.E.(1985).Sophisticated capital budgeting selection techniques and firm performance, The Accounting Review, LX (4),651-668. http://dx.doi: 10.1007/978-1-4899-7138-8_24

Halov, N., \& Heider, F. (2004). Capital Structure, Risk and Asymmetric Information. NYU Working paper, Available at: http://ssrn.com/abstract=566443 (Accessed: 05.05.2012)

Hermes, N., Smid, P., \& Yao,L. (2007). Capital budgeting practices: A comparative study of the Netherlands and China, International Business Review, 16(5),630-654. http://dx. doi:10.1016/j.ibusrev.2007.05.002

Herst, A., Poirters, S., \& Spekreijse, H. (1997).Capital budgeting practices in the Netherlands, Western Decision Sciences Institute. Available at:/http://www.sbaer.uca.edu/research/wdsi/wdsi.html(Accessed:20.04.2012).

Ho, S. S. M., \& Pike,R. H. (1998).Organizational characteristics influencing the use of risk analysis in strategic capital investment, The Engineering Economist,43(3),247-268. http://dx.doi:10.1080/00137919808903198

Hofer,C.W., \& Schendel, D. (1972).Strategy formulation :Analytical Concepts, New York:West Publishing Company

Holmen, M., \& Pramborg,B.(2009).Capital budgeting and political risk: Empirical evidence, Journal of international Financial Management and Accounting, 20(2),105-134. http://dx.doi.org/ 10.1111/j.1467-646X.2009.01028.x

Hornstein,A.S.(2013).Corporate capital budgeting and CEO turnover, Journal of corporate finance, 49-58. http:// dx.doi:10.1016/j.jcorpfin.2012.11.003

Ingersoll, J., \& Ross,S. (1992).Waiting to Invest: Investment and Uncertainty, The Journal of Business, 65(1),1-29. http://www.jstor.org/stable/2353172

Jensen, M. C.(1986).Agency Costs of Free Cash Flow, Corporate Finance, and Takeovers, American Economic Review, 76(2), 323-329. http://dx.doi.org/10.2139/ssrn.99580

Jog, M.J., \& Srivastava, A.K.(1995).Capital budgeting practices in corporate Canada, Financial Practice and Education, $5(2), 37-43$.

Jorion, P. (2006). Value at Risk - The New Benchmark for Managing Financial Risk, 3rd edn, New York: McGraw-Hill Higher Education.

Kersyte,A.(2011).Capital budgeting process:Theoretical Aspects, Economics and Management, 16(1),1130-1134.

Kester, G.,Chang,R.P., Echanis, E.S., Haikal, S. ,Md.Isa, M ., Skully, M.T., Tsui, K. C., \& Wang, C. J. (1999).Capital budgeting practices in the Asia-Pacific region: Australia, Hong Kong, Indonesia, Malaysia, Philippines, and Singapore, Financial Practice and Education, 9(1), 25-33.

Kester,G., \& Robbins,G. (2011).The Capital Budgeting Practices of Listed Irish Companies Insights from CFOs on their investment appraisal techniques, Accountancy Ireland, 43(1),28-30.

Khamees,B.H., Al-Fayoumi,N., \& Al-Thuneibat,A.A. (2010).Capital budgeting practices in the Jordanian industrial corporations, International Journal of Commerce and Management, 20(1),49-63. http://dx.doi.org/10.1108/10569211011025952

Klassen, K.J. (1997).The impact of inside ownership concentration on the trade-off between financial and tax reporting, The Accounting Review, 72(3),455-474.

Lazaridis, I.T.(2004).Capital Budgeting Practices: A Survey in the Firms in Cyprus, Journal of Small Business Management,42(4), 427-433. http://dx.doi.org/ 10.1111/j.1540-627X.2004.00121.x

Leon,F.M., Isa, M., \& Kester,G.W. (2008).Capital Budgeting Practices of Listed Indonesian Companies, Asian Journal of Business and Accounting, 1(2),175-192.

Libby, T., \& Waterhouse, J. H. (1996).Predicting change in management accounting systems, Journal of Management Accounting Research, 8,137-150.

Lintner, J.(1965).The Valuation of Risky Assets and the Selection of Risky Investments in Stock Portfolios and Capital Budgets, Review of Economics and Statistics, XLVII , 13-37

Magni, C.A.(2009).Correct or incorrect application of CAPM? Correct or incorrect decisions with CAPM?, European 
Journal of Operational Research, 192( 2),549-560.

Malkiel,B.G.(2003).The efficient market hypothesis and its critics, Journal of Economics Perspectives, 17(1),59-82

Mao,J.C.T.(1970).Survey of capital budgeting: Theory and practice, Journal of finance, 25(2),349-360.

Maquieira,C.P., Preve,L.A., \& Allende,V.S. (2012).Theory and practice of corporate finance: evidence and distinctive features in Latin America, Emerging Markets Review, 13(2),118-148

Markowitz, H. (1952). Portfolio Selection, Journal of Finance, 7(1), 77-91.

Markowitz, H. (1959) 'Portfolio Selection: Efficient Diversification of Investments', New York: Wiley.

Maroyi,V., \& Poll,H.M.(2012).A survey of capital budgeting techniques used by listed mining companies in South Africa, African Journal of Business Management,6(32), 9279-9292.

McGrath, R.G., \& Nerkar, A. (2004).Real options reasoning and a new look at the R\&D investment strategies of pharmaceutical firms, Strategic Management Journal, 25(1),1-21.

McGrath, R.G., Ferrier, W.J., \& Mendelow, A.L.(2004).Response: real options as engines of choice and heterogeneity, Academy of Management Journal, 29(1),86-101.

Miles, M., \& Huberman, M. (1984). Qualitative Data Analysis, Beverly Hills CA: Sage.

Miller, K. D., \& Waller, H.G. (2003).Scenarios, real options and integrated risk management, Long Range Planning, 36, 93-107.

Miller, M., \& Modigliani. F. (1961).Dividend Policy, Growth, and the Valuation of Shares, Journal of Business, 34(4), 411-433.

Modigliani, F., \& Miller, M.H. (1958). The Cost of Capital, Corporation Finance, and the Theory of Investment, American Economic Review, 48(3),261-297.

Mukheijee, T. K., \& Henderson, G. V.(1987).Capital Budgeting Process: Theory and Practice, Interfaces, $17(2), 78-90$.

Murto, P., \& Keppo, J. (2002). A game model of irreversible investment under uncertainty, International Game Theory Review, 4(2),127-140

Mustapha, M. Z., \& Mooi, S. T. L. (2001). Firm Performance and Degree of Sophistication of Capital Budgeting Practice: Some Malaysian Evidence,Proceedings of the Asia Pacific Management Conference, 279-290.

Myers,S.C.(1977). The Determinants of Corporate Borrowing, Journal of Financial Economics 5(2),147-175.

Myers, S.C. (1984).The capital structure puzzle, Journal of Finance ,39,575-592.

Myers, S.C. (2003).Financing of corporations. Constantinides, G., M. Harris, and R. Stulz (eds.) Handbook of the Economics of Finance', Corporate Finance Volume 1A, Elsevier North Holland.

Nutt, P.C. (1993).Flexible Decision Styles and the Choices of Top Executives, Journal of Management Studies, 30(5), 695-721.

Pandey, I, M.(1989).Capital Budgeting Practices of Indian Companies, Management Journal, 2(1), 1-15

Payne, J. D., Heath, W. C., \& Gale, L. R. (1999).Comparative financial practice in the US and Canada: Capital budgeting and risk assessment techniques, Financial Practice and Education, 9(1), 16-24.

Peterson, P. P., \& Fabozzi, F. J. (2002). Capital Budgeting: Theory and Practice, New York: Wiley and Sons.

Pike, R., \& Neale,B. (2009). Corporate finance and investment decisions and strategies, 6th edn., Harlow: Pearson Prentice Hall.

Pike,R.(1996).A longitudinal survey on capital budgeting practices, Journal of Business financing and Accounting, 23(1),79-92.

Pike, R. H.(1988). An empirical study of the adoption of sophisticated capital budgeting practices and decision making effectiveness, Accounting and Business Research , 18(Autumn), 341351.

Rigopoulos, G. (2014). Real Options Adoption in Capital Budgeting: A Highlight of Recent Literature, Journal of Economics and Business Research, 20(2),41-51.

Ritter, J. R. (1991).The Long Run Performance of Initial Public Offerings, Journal of Finance, 46(1), 3-27.

Rogers, E.M. (1995). Diffusion of Innovations, 4th edn., New York: Free Press.

Roll, R. (1977).A Critique of the Asset Pricing Theory's Tests' Part I: On Past and Potential Testability of the Theory', 
Journal of Financial Economics, 4(2),129-176

Ross, S.A., Westerfield, R.W., Jordan, B.D., \& Roberts, G.S.(2005). Fundamentals of Corporate Finance, 5th Canadian edn., Ryerson, Toronto: McGraw Hill,.

Ross,S.A.(1976). The Arbitrage Theory of Capital Assets Pricing, Journal of Economic Theory, 13(3), 341-360.

Ryan,P.A., \& Ryan,G.P.(2002).Capital budgeting practices of the fortune 1000: How have things changed?, Journal of Business and Management, 8(4),355-364.

Sangster, A. (1993). Capital investment appraisal techniques: A survey of current usage, Journal of Business Finance and Accounting, 20(3), 307-332.

Segelod, E. (1998). Capital budgeting in a fast-changing world, Long Range Planning, 31(4), 529-541.

Sekwat, A. (1999). Capital budgeting practices among Tennessee Municipal Government, Government Finance Review (June),15-19

Shahrokh M. S.(2002). Multinational Capital Budgeting. Available at: http://www.thehindubusinessline.com.

Shank, J. K., \& Govindarajan, V.(1992). Strategic Cost Management: The Value Chain Perspective, Journal of Management Accounting Research, 4, 177-197.

Shao, L. P., \& Shao, A.T. (1996).Risk Analysis and Capital Budgeting Techniques of U.S. Multinational Enterprises, Managerial Finance, 22(1), 41-57. http://dx.doi.org/10.1108/eb018542

Sharpe,W.F.(1963). A simplified model of portfolio analysis, Management Science, 9(2), 277-293. http://dx.doi.org/10.1287/mnsc.9.2.277

Sharpe,W.F.(1964).Capital Assets Prices: A theory of market equilibrium under conditions of risk, Journal of Finance,19(3), 425-442. http://dx.doi.org/10.1111/j.1540-6261.1964.tb02865.x

Shinoda,T.(2010).Capital Budgeting Management Practices in Japan - A Focus on the Use of Capital Budgeting Methods, Economic Journal of Hokkaido University, 39(2010), 39 - 50.

Shleifer, A. (2000). inefficient markets: An introduction to behavioral finance, Oxford, UK: Oxford University Press.

Simerly, R.L., \& Li,M.(2000).Environmental Dynamism, Capital Structure and Performance: A Theoretical Integration and an Empirical Test, Strategic Management Journal, 21(1), 31-49. http://dx.doi.org/ 10.1002/(SICI)1097-0266(200001

Singh,S., Jain,P.K., \& Yadav,S.S. (2012).Capital budgeting decisions : evidence from India, Journal of Advances in Management Research, 9(1),96-112. http://dx.doi.org/10.1108/09727981211225671

Slagmulder, R., Bruggeman,W., \& Wassenhove,L.(1995).An Empirical Study of Capital Budgeting Practices for Strategic Investments in CIM Technologies, International Journal of Production Economics, 40(2),121-152. http://dx.doi.org/10.1016/0925-5273(95)00069-7

Smit, H.T.J.( 2003).Infrastructure investment as a real options game: the case of European airport expansion, Financial Management, 32(4),27-57. http://www.jstor.org/stable/3666135

Smit, H.T.J., \& Ankum,L.A.(1993). A Real Options and Game-Theoretic Approach to Corporate Investment Strategy under Competition, Financial Management, 22(3), 241-250.

Staw, B. M. (1991). Dressing Up Like an Organization: When Psychological Theories Can Explain Organizational Action, Journal of Management,17(4),805-819. http://dx.doi: 10.1177/014920639101700412

Strauss, A., \& Corbin, J.(1998). Basics of qualitative research: Grounded theory procedures and techniques, Newbury Park, CA: Sage Publications.

Trahan, E. A., \& Gitman, L.J. (1995).Bridging the Theory-Practice Gap in Corporate Finance: A Survey of Chief Financial Officers, Quarterly Review of Economics and Finance, 35(1), 73-87. http://dx. doi.org/10.1016/1062-9769(95)90063-2

Trigeorgis, L.(1993).Real options and interactions with financial flexibility,Financial Management, 22(3),202-224.

Truong, G.,Partington,G., \& Peat,M.( 2008). Cost of capital estimation and capital budgeting practice in Australia, Australian Journal of Management, 33(1),95-121. http://dx.doi.org/10.2139/ssrn.1019962

Verbeeten, F. H. M. (2006). Do organizations adopt sophisticated capital budgeting practices to deal with uncertainty in the investment decision? A research note, Management Accounting Research, 17(1), 106-120. http://dx. doi.org/10.1016/j.mar.2005.07.002 
Verma,S., Gupta,S., \& Batra,R.(2009).A Survey of Capital Budgeting Practices in Corporate India, The Journal of Business Perspective,13(3), 1-17.http://dx.doi.org/ 10.1177/097226290901300301

Warfield, T.D., Wild J.J., \& Wild, K.L. (1995). Managerial ownership, accounting choices, and informativeness of earnings, Journal of Accounting and Economics, 20(1),61-91.http://dx. doi.org/10.1016/0165-4101(94)00393-J

Williams, J.J., \& Seaman, A.E. (2001).Predicting change in management accounting systems: national culture and industry effects, Accounting, Organizations and Society, 26(4),443-460. http://dx. doi.org/10.1016/S0361-3682(01)00002-2

Young, K., Ashby, D., Boaz, A., \& Grayson, L. (2002).Social science and the evidence-based policy movement, Social Policy \& Society, 1(3),215-24. http://dx.doi.org/10.1017/S1474746402003068

Zhang, Q., Huang, X., \& Tang, L. (2011).Optimal multinational capital budgeting under uncertainty, Computers and Mathematics with Applications ,62(12), 4557-4568. http://dx. doi.org/10.1016/j.camwa.2011.10.035

Zhu, K., \& Weyant, J. P. (2003).Strategic decisions of new technology adoption under asymmetric information: a game-theoretic model, Decision Science,34(4), 643-675. http://dx.doi.org/ 10.1111/j.1540-5414.2003.02460.x

\section{(c) $)$ EY}

This work is licensed under a Creative Commons Attribution 3.0 License. 